\title{
Paulina Kwiatkowska
}

University of Warsaw

\section{Zofia Dwornik:}

\section{Becoming a Female Film Editor}

In this article I intend to recall and shortly present the figure of Zofia Dwornik, one of the most appreciated and nowadays rather forgotten female film editors of post-war communist Poland. Born in 1922 and deceased in 2002, Dwornik cooperated, for the twenty-five years of her creative activity, in the production of more than thirty films with the most prominent directors of the Polish cinema in the 1950's, 60's and 70's. She co-created, among others, films of Jerzy Kawalerowicz (Pod gwiazda frygijska [Under the Phrygian Star], 1954- her independent debut as a film editor), Andrzej Munk (Pasażerka [The Passenger], 1963 - she joined the film crew after director's death), Krzysztof Zanussi (Struktura krysztatu [The Structure of Crystals], 1969), Grzegorz Królikiewicz (Na wylot [Through and Through], 1972), Andrzej Wajda (Ziemia obiecana [The Promised Land], 1974 - together with Halina Prugar), Witold Leszczyński (Rekolekcje [The Retreat], 1977) and Tomasz Zygadło (Rebus [The Rebus], 1977 - her last film). The longest, however, was her cooperation with Wojciech Jerzy Has, with whom she finished Film Education Course in Cracow already in 1946. With the exception of Rękopis znaleziony $w$ Saragossie (The Saragossa Manuscript, 1964), Dwornik edited all films of Has in the 1950's and 60's, starting with his debut film Pętla (The Noose, 1957), through Pożegnania (Farewells, 1958), Wspólny pokój (Roomers, 1959), Rozstanie (Partings, 1960), Ztoto (Gold Dreams, 1961), Jak być kochand (How to Be Loved, 1962), to Szyfry (The Codes, 1966) and Lalka (The Doll, 1968). 
In the Polish post-war cinema, the profession of film editor was strongly feminized. The reasons for this fact were complex and at the same time quite prosaic - I will return to this issue later in the article. In the case of Dwornik, her decision to choose this particular profession was, however, based on additional objective considerations, closely related to the context of post-war changes of the system as well as the social relations and the general moods of the Stalinist period in Poland. The above-mentioned films co-created by Dwornik leave no doubt that she was a real artist in her profession, highly valued by directors, who trusted her technical skills and artistic sensitivity. Nevertheless, it should be remembered that film editing was not a career of her first choice - she had wanted to become a director and, presumably, an independent filmmaker.

In my article, I intend to take a closer look not so much at the achievements of Dwornik in the 1960's and 70's, but at the complex circumstances that influenced her later career. Therefore, I will be interested in the years of her studies and the atmosphere prevailing in the Polish film environment in Cracow and Łódź in the first years after World War II. I shall try to reconstruct the most important moments in Dwornik's student and professional life during this period and analyse one of the film études she made in the Film School in Łódź, in order to examine the reasons of her decision to become a film editor. This will also allow, as I assume, to formulate some hypotheses how her career might have developed, had she been given the chance to graduate and try her hand at directing.

Professional biography of Dwornik, but also to an extent her private life, is, on the one hand, a testimony of an individual drama, inscribed in the reality of the Stalinist period in the post-war Poland. As she put it herself: "The Katyn affair affected heavily my entire life" (Miller, 1998, p. 241) - including to a large extent her creative life, one may add. On the other hand, her story and personal choices may well be deemed as symptomatic of women's position in Polish cinema of that period ${ }^{1}$.

Her father Stefan Dwornik was a Polish Army major, who retired in 1929, but with the onset of the Second World War was enlisted in army and took part in the defence of Lviv. Wounded and taken captive when the city surrendered, he ended up, as it turned out decades later, in a camp in Starobielsk, a place, as Dwornik mentioned, from which he sent his last two messages to the fam-

In the reconstruction of crucial moments of Zofia Dwornik's private and professional life, my sources are Filip Gańczak's article Katynskie piętno (The Stigma of Katyn, 2017), the memories of Zofia Dwornik herself and of other students of Film Education Course in Cracow and Film School in Łódź (Albrecht, 1998; Miller, 1998), and a short TV documentary Zofia Dwornik - skazana za Katyń (Zofia Dwornik - Condemned for Katyn) made by Magdalena Majewska for the Third Polish TV Channel and broadcast for the first time on 16th October 2018. 
ily (Miller, 1998, p. 38). In spring 1940, he was transported to Kharkiv along with other Polish prisoners-of-war. He was executed there by the NKVD, Soviet secret police, and buried in a collective grave. From 1940, Zofia Dwornik was a courier of the Association of Youth Fight, and then of the Home Army. Benefitting from underground education, she passed her graduation exam during the war. In 1945, she began to study photography in Tarnów, only to move a year later to Cracow, where she finished Film Education Course together with, among others, Wojciech Jerzy Has, Jerzy Kawalerowicz, Jerzy Passendorfer and Mieczysław Jahoda. She then moved to Łódź, where she was employed by Polish Film National Enterprise, as an assistant film editor, studying at the same time for one year the history of arts and attending a film study, which in 1948 was transformed into Higher School of Film (later National Higher School of Film). Dwornik was accepted to the Department of Film Direction, straightaway to the second year of studies, because she was given credit for the earlier Film Education Course and film study. As a student, she worked in the Polish Film Chronicle as a film editor, she was also an assistant director and was recognized as a "gifted, diligent and disciplined" student, as one can read in a document preserved in the archives of the Film School ${ }^{2}$.

In order to understand the further history of Dwornik, it is important to examine more closely the nature both of the private and the purely professional relations that prevailed in the film studios in Cracow and in Łódź. An important difference is immediately noticeable. The Film Education Course in Cracow, which ran only for seven months from the end of 1945 to July 1946, was not strictly institutionalized and was only to some extent controlled by the central authorities at the level of the relevant ministry or the Polish Film National Enterprise, which at that time was organizing its structures in Łódź. The person responsible for the organizational structure and teaching in Cracow was Antoni Bohdziewicz - widely adored by students, but raising increasing doubts of the authorities. He knew how to take advantage of the fact that in the first years after the war not only Polish cinema, but also the state and ideological structures themselves were only in the process of consolidation. The freedom allowed before 1948, was difficult to defend later, after the creation of the Polish United Workers' Party, and even more so after 1949, when artistic circles one after another were obliged to adopt the social realist doctrine (filmmakers during the Congress in Wisła in November 1949). Many years later, in a volume devoted to film education in Cracow in the years 1945-1947, students of the Film Education Course remembered the months of study as a time of freedom, primarily creative free-

2 Archives of the Leon Schiller National Higher School of Film, Television and Theater in Łódź, Files of Zofia Dwornik, Questionnaire regarding the granting of a scholarship, Łódź, 11 January 1949, p. 18. 
dom, and emphasized that a safe distance from Warsaw or Łódź, perhaps even a sense of isolation from the surrounding reality, allowed them to focus primarily on developing their passion for the cinema. Dwornik succinctly and emotionally summarized the atmosphere during the course: "The most important was probably that everyone surrounded us with warmth and kind understanding. We were still anxious of the camera, of the world that had to be tamed and called for personal expression, of surrendering to one's own artistic vision" (Albrecht, 1998, p. 67). Those short, but intense months turned out to be formative both in the artistic and social dimension. Wojciech Has mentioned that "acquaintances and friendships made during film education showed results in my later professional career - Skarżyńscy, Mietek Jahoda, Zosia Dwornik were people with whom we understood each other perfectly, almost without words. We've made a couple of pretty good films together" (Albrecht, 1998, p. 90).

This atmosphere of community was never fully recreated or built at the Film School in Łódź. Reading the numerous memories of students in the first years of their studies, one can obviously get the impression that, compared to the reality outside of school, their situation was extremely favourable, and they associated their school years primarily with a sense of freedom, intense social life, and hard but fascinating work. As Joanna Preizner notes in her book analysing student études from the years 1949-1960, the general overtones of these statements are often largely determined by strong nostalgia for youth, for the relative carelessness that to a limited extent the school offered (2007, p. 30). However, there are also statements that supplement and correct this optimistic picture, reminding of the difficult living conditions (constant lack of money, living in a crowded dormitory, sometimes malnutrition and exhaustion), but above all of the sense of uncertainty and threat. Preizner points out that "what probably most influenced the sense of insecurity and was effectively destroying interpersonal relationships was the awareness of permanent surveillance and the need to constantly be careful even with the smallest words and gestures, which could be noticed by an apparently friendly schoolmate and ruin one's life for at least a few years" (2007, p. 29). Film students were under constant surveillance of the officers of the Department of Security, whereas within the school the Academic Union of Polish Youth (since 1950 incorporated in the structures of the Union of Polish Youth) was developing its vigorous actions: not only did its members have a significant impact on the school's teaching activities, but they would also intervene during the events organized by students or make denunciations of specific persons. Interestingly, Dwornik also decided to join the Union together with a then-friend of hers Jadwiga Zawadzianka (after wedding - Żukowska) in order to "find out what this socialism actually was, because we had been 
brought up in a completely different worldview" (Miller, 1998, p. 32). They were accepted only conditionally, because they were recognized as a "foreign element". This episode shows perfectly well that everyday life at school by necessity required to remain vigilant, to constantly adapt to the changing circumstances, often only for the sake of appearances, to seek one's place in the emerging social and professional structures.

When Zofia Dwornik began her education in Łódź, she was already a somewhat recognizable person in the environment, but as it seems, she was also considered "ideologically uncertain" due to her own and her family's story from the pre-war and war period. As she said, and not only on her own behalf, "the school was an enclave in which, overwhelmed by the weight of war experiences, we tried to restore the carefree youth. We would largely succeed in this, but unfortunately not always" (Miller, 1998, p. 38). The atmosphere of that time and place was even more vividly expressed by Kazimierz Sheybal, a close acquaintance of Dwornik from the Film Education Course and Film School, who strongly emphasized that the months spent in Cracow gave him more than the entire period of study in Łódź. It was the course, so warmly remembered by Dwornik, that gave him "strong philosophical and theoretical foundations for practicing his profession that were never given to anybody in Łódź, where in that period politics meant more than knowledge, and the first few years were marked by 'witch-hunt" (Albrecht, 1998, p. 63). As it later turned out, Dwornik was probably the one who experienced the mechanisms of this witchhunt the most. One may wonder whether this was connected only with her attitude and views, or perhaps also, at least to some extent, with the fact that she was a woman.

In a volume dating from the beginnings of the 1990's, collecting memories of students of the Film School in Łódź in the period of communist Poland, there are only few quotes of Dwornik's words apart from those mentioned above most of them concern her denunciation, the trial and her disappointment with the closest school friends. However, in one of her utterances, she draws attention to yet another aspect of the school's functioning, as she outlines the atmosphere of that time and place - seemingly quite unconstrained, allowing even for some sort of protest or attempt to actively decide about one's position in the school hierarchy. But in fact, her words disclose, above all, one aspect of the discrimination of women in the school and their full awareness of the fact; their feeling of some indefinable threat from various state services and finally a possible reason of antipathy towards Dwornik, which resulted in her further troubles. Let me quote her words at length: 
There were only a few girls at school. We all had private lodgings, somewhere in the suburbs of Łódź, paying costly rents for miserable, tiny rooms, while at the other side of the boys' dormitory, within the school grounds, a three-room apartment with a bathroom was being prepared for the headmaster Wimmer. But the apartment stood empty and it began to itch our imagination. Why - we pondered over the injustice of the woman's fate - boys always have it easier in life? Why do we have to be getting up at six in the morning, while for them it is enough to drag themselves out of beds five to eight, paying not a penny for such luxuries? All rebellious, asking for no one's permission, we took the apartment. Of course, attempts were made to have us removed, to threaten us with police, with the commission of social norms, until at last Leon Wol explained to us that if boys and girls stayed in the same place, it would just be a mess. I heartily assured him that nothing of the kind would happen, there would be no mess, I would see to it myself. And so I did and played the role of the stereotyped Polish mother. As I wasn't myself much inclined to romance, I tried to cool down the exuberant tempers of some couples, but all in all Leon Wol's life experience proved to be greater than mine (Miller, 1998, p. 23).

In one of the rooms in the apartment within the school grounds which they eventually managed to keep, Dwornik lived together with Nina Fleiszer from the Department of Cinematography and Jadwiga Zawadzianka from the Department of Film Direction, but in fact partners, and later husbands of both women, would also occasionally stay there. Wadim Berestowski was in relationship with Fleiszer and Witold Żukowski with Zawadzianka, both men from Department of Film Direction. One can read in the memoirs that this situation caused increasing conflicts - Dwornik did not like the way Berestowski would abuse his partner, already pregnant at that time; he, in turn, found it bothersome that Dwornik would "butt into their affairs"; he also claimed that "Miss SelfReliance" did not attract that much sympathy in school, for she would sometimes be aggressive (Miller, 1998, p. 39). In the evening of 17 September 1950 - Dwornik was formally in the fourth year of her studies - all five of them met again in the dormitory for women. According to testimonies of the participants of that meeting, which are preserved in the archives of the Institute of National Remembrance and which all agree as to facts, though not as to their interpretation, Berestowski would at some point provoke Dwornik, asking her how it was possible for her to be in such a good mood and so cheerful on the day of a sad anniversary - the anniversary of the Red Army's invasion of Poland on 17th September 1939, and which could not be officially alluded to in the communist Poland. Dwornik admitted it was a tragic anniversary for her and mentioned 
her father who had been murdered - as she then believed - in Katyn, because it was there that a German commission already during the war, in 1943, had discovered mass graves of Polish officers. In further conversation, she also admitted she knew the crime had in all probability been committed by the Russians who - in contrast to German army - would not even inform of the date and place of death of camp prisoners and of war captives. In the trial, this became a pretext for accusing Dwornik of claiming that the Red Army was guilty of the crimes then ascribed to the Hitler's Germany and of whitewashing the fascism. On 20 October 1950, she was arrested by the officers of the Department of Security in Łódź and accused of committing a crime pursuant to article 22 of the Decree on the Particularly Dangerous Crimes in the Period of State Restoration, which spoke of spreading false information that may impair the interest of the Polish State. On 31 January 1951, Dwornik was sentenced to a year of deprivation of liberty and sent to a labour camp.

The circumstances of the provocation itself and denunciation by persons who were close to Dwornik remain complex. Years later, Berestowski, by then a respected director of feature and animated films for children, thus commented on his conduct: "I don't really know why this should have happened to me... Foolishness, lack of awareness, lack of consequence..." (Miller, 1998, p. 241). He also argued that due to her anti-communist views Dwornik was a threat to the school. As it appears from the case files and the scattered memories, other persons from the school were also involved in these events, primarily members of the Union of Polish Youth. Filip Gańczak, analysing the case files and other documents collected in the archives of the Institute of National Remembrance, argues that the arrest and conviction of Dwornik could also have been influenced by the denunciation of Jerzy Lipman, an eminent operator, then a film school student, who in 1948-1955 under the pseudonym "Hedgehog" collaborated with the Security Service. At the trial, the testimonies of Berestowski and Zukowski were the ones that most severely incriminated Dwornik, but also her closest female friends decided to stand against her. Zawadzianka explained her attitude with anxiety - the systemic anxiety ("Once the affair was proclaimed aloud, there was no turning back. From then on we all feared one another." [Miller, 1998, pp. 39-40]), but also a more individual one ("When Zosia was arrested, I was pregnant. I was very scared, I didn't want to lose my child. I thought - what would it help if I were the only one not to testify. It was only the truth I was telling..." [Miller, 1998, p. 41]). It is not the point now to assess these attitudes from today's perspective - the fear for oneself and the loved ones, the ignorance of deeper mechanisms governing reality, succumbing to the influence of betteroriented people, but also some isolation within the school walls from the world 
outside - all of that certainly led to the situation when all were talking about Dwornik's case, but no one stood up to explicitly defend her. Janusz Morgenstern gives probably the most complete summary of those events, though perhaps not without some bitterness: "The arrest of Zosia Dwornik particularly shocked us, but we were separated from the city by a high fence and with time, it was our youth and hope for the future that prevailed" (Miller, 1998, p. 81).

However, it seems that Dwornik had never come to terms with those events and never forgave her former friends who destroyed her career. When she returned to Łódź, she wanted to continue with her studies, but she was only allowed to take final exams and obtain a certificate of completion of the studies, but not a diploma in film direction, which meant, in the reality of communist Poland, that she could not work as a film director, not even as an assistant. It cost her much effort to find a year-long employment in dubbing - she did not like the job, and moreover, she was constantly urged to collaborate with the Department of Security. In 1954, Jerzy Kawalerowicz lent her a hand, offering a job as a film editor of Under the Phrygian Star. On the day when she officially started to work as a film editor, her mother was dismissed from work with the information that she should not inquire about the reasons. It was not until 1992 that Dwornik managed to have the sentence overturned.

***

Unfortunately, apart from a few scattered utterances, no interviews with Dwornik of a more substantial volume have ever been made, which - especially if they were made after 1989 - could throw some light not so much on her further private life, but above all on her attitude towards film editing, which was her profession for almost twenty-five years. It is certain that her goal had been to become a director, whereas film editing, which she practiced with undoubted talent, proved to be the only way to stay as close as possible to filmmaking. But we cannot establish what her own understanding of her role was, nor whether she perceived herself as part of some larger environment. We can only presume that some sort of distance or withdrawal were in her case connected not only with the objective role ascribed at that time to the "invisible work of women" in the cinema industry, but also with her subjective experiences of exclusion and betrayal.

I would like to propose a number of viewpoints, from which one may look at the creative accomplishments of Dwornik at the very beginning of her career, and try to indicate perhaps certain stylistic or narrative traces that her hand might have left on the early footage. It seems interesting to me to take a more attentive look at the student études she worked on and to treat them as testimonies, 
on the one hand, of a certain intuition and sensitivity which are characteristic of a director, and on the other - of gradually improving techniques and editor's awareness.

The first issue is related to the perspective of the alternative film history and to the question of those facts from the film history which only ever existed potentially and never took place. During her studies in Łódź, Dwornik created two documentary film études, Wiejski talent (A Country Talent) in 1949 and Pielegniarki (Nurses) in 1950 - both of which she directed on the basis of her own scripts. As one watches the latter film Nurses, available on the website of the Film School archives ${ }^{3}$, one may be inclined to ponder how her career as a film director might have developed. Admittedly, the film adheres to the commonly accepted pattern at that time of a social realist documentary - it has a strong propaganda message with little nuance of theses concerning the social utility of the profession of a nurse. Seemingly, the étude is rather informative in style, aiming at generalizations. Shot after shot, nurses are presented to us at various stages of their education and career (at nursing school, on the way to patients, in the company clinic, in the hospital or in the sanatorium), with the focus on collective experience. Yet this is not an objective description of nurses' life - next to or beneath a strongly propaganda offstage commentary by a male narrator, Dwornik builds a short story not quite lacking individual features. In some scenes, we recognize the same nurses and what is more, it gradually turns out that the film has also an individual heroine. A young girl from the country, Teresa (the only one whom we know by name) shows great interest in the work of a nurse, and even some talent in this field. Later in the film, we will see her filling in the papers for admission to school and finally learning the profession in the company of other women. Of course, this microhistory can be treated as an example of a narrative pattern typical of social realism, telling an optimistic story of social advance, the emergence of class consciousness and crossing the barriers erected on the women's path to education and professional independence. This is the tone of Joanna Preizner's interpretation of Dwornik's étude. She notes that - as in many other études or documentary and feature films of the Stalinist period - a woman (as well as a child) is portrayed as a raw and passive material that still needs to be shaped. The researcher emphasizes that when the off-stage narrator describes the heroine, he uses the words "Teresa's interests and properties must be directed to the right track". Hence the conclusion that "Teresa does not decide for herself, nor is she treated as an independent entity that

3 Available at: https://etiudy.filmschool.lodz.pl/material/Pielegniarki_Prores422HQ_25fps_1920x1080_ Lin_sn10?search_type=fulltext\&query= [access: 21.01 .2020$]$. 
has features - not properties, as metal or plastic do" (Preizner, 2007, p. 193). However, it seems that these diagnoses are worth supplementing and perhaps also correcting.

The very choice of female characters and of situations, in which they are presented, indicates a very individual attitude of Dwornik to the subject. First of all, a story of hardships, challenges and joys of nurses' work allows one to focus on the often little appreciated and hardly visible work of caretaking and assistance performed by women. What is important, Dwornik presents nurses mainly in their relations with other women (female patients in hospitals and village clinics or the poorest representatives of workers, which the nurses try to reach with free-of-charge assistance) or with children (among others, in the department of obstetrics and in a tuberculosis sanatorium for children). This allows to emphasize female relationships, also those built around bodily experiences - above all those of pregnancy, giving birth and childcare. Clearly enhanced is the role of a mother; however, as the final commentary in the film concludes with a strain of pathos, equally "justified is the pride of a nurse. She knows she is watching over a healthy growth of the nation's future generation - a generation of peace!" This focus on the subject of femininity is also underlined by the very manner of framing - the film is dominated by close-ups, which present emotions of nurses and their female patients and underline the intimacy of their relationship. Men, if they appear, even as doctors or persons theoretically of a higher standing in hierarchy, are often portrayed in the back plan of a shot, as if they were merely a background. All these are subtle procedures, yet they endow this simple and seemingly not very original film with a distinctly female perspective, which cannot be masked or weakened even by the commentary read by a man. On the contrary, a man's voice pronouncing the parts of women (nurses and their female patients) sounds artificial and out of place in the strongly feminized world represented in the film. If Dwornik had the chance to produce her own independent films, perhaps the subject of femininity could resound more fully - expressed, this time, with a female voice.

If we agree that depriving Dwornik of the possibility to become a director meant, in the context of film production practices in communist Poland, depriving her of voice, impeding the possibility of expressing herself independently and on her own behalf, then the question is worth asking - and this is the second issue I would like to signal here - whether the fact that she became a film editor allows us to notice traces of her touch in the films she worked 
on. Another school film étude, entitled First Film Études (Pierwsze etiudy), produced in 1949 by Kazimierz Sheybal ${ }^{4}$, documents the creation of film études by students of Film School in Łódź in the Polish Film studio, which they were free to use. At the beginning, the film presents an essentially social realistic criticism of the pre-war cinema, the patterns of which are to be ultimately overcome by the youngest generation, which is now studying to enter the profession. We may see consecutive stages of work on the film études and students engaged in various activities of film shooting. Towards the end of the film, we can see three shots presenting Zofia Dwornik, who, in accordance with her field of study, is identified in the film description as a director, but in the film itself - which, in the context of the above described events, may be interpreted symbolically - she is presented at a film editing table along with two other women, as she is cutting and gluing together bits of footage. A frontal view of Dwornik, scissors in her hands, is thus commented off-stage: "Scissors have a decisive meaning for the future film".

Interestingly enough, the statement itself seems to comply with the dominant theories of film editing, which would underline that this is one of the key moments of film production, when that which until now functioned as a text (screenplay, shooting script) or scattered material (raw footage, double shots, audio track, music etc.) becomes a coherent whole. Hence it is only on the film editing table that a potential film becomes a real one. However, it is difficult to avoid the impression that this appreciation of film editing as a stage of film production does not entail appreciation of the profession of a film editor - especially as long as it was a profession mainly associated with women, and this was the case practically all throughout the communist period in Poland.

Film editing was back then (next to makeup, costume design and scenography) one of the few largely feminized film professions. Polish films (feature and documentary) were co-created by, among others, Lidia Zonn, Jadwiga Zajiček, Halina Prugar, Maria Orłowska, Krystyna Komosińska, Wanda Zeman, Elżbieta Kurkowska, Irena Choryńska, Hanna Kłoskowska and many others. Some of them in fact studied film directing as Dwornik did, but for various reasons and at different stages of their career they changed their profession. Searching for reasons of this situation, Zonn and female film editors the conversations with whom she published in the book W montażowni - wczoraj (In the Editing Room - Yesterday) (as an aside - no conversation with Zofia Dwornik was included) point to the hierarchical structure of Polish educational system and film indus-

4 Available at: https://etiudy.filmschool.lodz.pl/material/Pierwsze_etiudy_

Prores422HQ_25fps_1920x1080_Lin_sn10?search_type=fulltext\&query=pierwsze+etiudy [access: 29.01.2020]. 
try and to the much repeated argument concerning specifically "female" traits of character (patience, meticulousness, manual skills), which were supposed to predestine them to film editing 5 . In the conversations included, also with film directors, there are reflections on the effects of such feminization of the profession of a film editor and questions about the relation between director and editor and the impact of this relation on the final shape of the film. Stanisław Różewicz compared the hands of female film editors in white gloves to the hands of a surgeon: "Female film editors - he added - precise and patient, know everything about their film directors, about their weaknesses and breakdowns, their fleeing from editing room" (Zonn, 2008, p. 23). Piotr Szulkin perceived these relations in even more intimate categories:

The relationship between a film director and a female film editor has much in common with the relationship of a patient female lover and her traumatised partner. Every film director feels crumbled after the shooting period. [...] To forget it all, the presence of someone close and patient is indispensable. This is also the role of a female film editor. I have never done film editing with a male editor. And I can't imagine it (Zonn, 2008, p. 29).

Hence the work of a film editor would by necessity be hidden, as it potentially discloses the weaknesses and anxieties of a director. It would be of fundamental importance, most of all because it would enhance and confirm the director's talent or, on the contrary, it would expose the shortcomings of his techniques. Unfortunately, it would also be a work inevitably lacking independence, even if, as it was with Andrzej Wajda (Zonn, 2008, p. 78), the editor was to work in solitude, without any direct interference on director's part. For even in such situations, her aim should be to understand the director's intentions and apply them to the final editing structures of the film.

Is it possible at all to avoid this way of defining the role of a female film editor and her relation with the director? Does a long-term cooperation with a director - as it was with Dwornik and Has - enhance this kind of at times intimate interdependence and common responsibility, or perhaps, paradoxically, it allows the female film editor to develop her own style? Is it possible at all and reasonably grounded to analyse films produced in the communist period in Poland concentrating precisely on the style of given female film editors? These questions go far beyond the scope of this article, as they require a precise comparative analysis of

5 Maria Orłowska (Zonn, 2008, p. 57), Halina Prugar (Zonn, 2008, p. 73) and Łucja Ośko (Zonn, 2008 , p. 91) mentioned that during job interviews for the position of film editors, they were asked if they had the ability to do needlework or if they liked to sew. 
many films of Has edited by Dwornik. Yet it seems that quite an inspiring theoretical tool to apply at this work may be the sensuous film theory, which allows to overcome the domination of sight in our thinking about film and to appreciate the importance of other sensuous relations, in which both the spectator and the creator are engaged with the film image. And one can hardly think of a more sensuous and physical relation than the one between the hand of a female film editor and the footage she handles.

\section{References}

Albrecht, J. (ed.) (1998). Prafilmówka krakowska 1945-1947. Nauczyciele - stuchacze filmy. Kraków: Wydawnictwo Filmotechnika.

Gańczak, F. (2017). Katyńskie piętno. Biuletyn IPN, no. 4. Available at: https://pamiec.pl/ pa/teksty/artykuly/19729,KATYNSKIE-PIETNO-tekst-dr-Filipa-Ganczaka-z-numeru42017-quotBiuletynu-IPNquot.html [access: 25.01.2020].

Miller, M. (ed.) (1998). Filmówka. Powieść o Łódzkiej Szkole Filmowej. Warszawa: Prószyński i S-ka.

Nagurska, E. (1988). Szkic do portretu szkoty filmowej. Łódź: Wydawnictwo Muzeum Kinematografii, Państwowa Wyższa Szkoła Filmowa, Telewizyjna i Teatralna.

Pałczyński, E. (1989). Pierwsze lata szkoty X Muzy. Łódź: Wydawnictwo Muzeum Kinematografii.

Preizner, J. (2007). PRL w obiektywie studentów tódzkiej filmówki w latach 1949-1960. Kraków: Rabid.

Zonn, L. (2008). W motażowni - wczoraj. Łódź: Państwowa Wyższa Szkoła Filmowa, Telewizyjna i Teatralna.

Zonn, L. (2001). Wokót montażu. Wybór tekstów źródtowych. Łódź: Państwowa Wyższa Szkoła Filmowa, Telewizyjna i Teatralna. 


\begin{abstract}
In this article the author intends to recall the figure of Zofia Dwornik, one of the most appreciated and nowadays rather forgotten female film editors of post-war communist Poland. For the twenty-five years of her creative activity, Dwornik cooperated in the production of more than thirty films with the most important directors of the Polish cinema in the 1950s, 60s and 70s. In the Polish post-war cinema, the profession of film editor was strongly feminised. In the case of Dwornik, her decision to choose this particular profession was, however, based on additional objective considerations, closely related to the context of the Stalinist period in Poland, and was not her first choice of career - she had wanted to become a film director. In this article the author takes a closer look not so much at the achievements of Dwornik in the 1960s and 70s, but at the complex circumstances that influenced her later career. Therefore, the author tries to reconstruct the most important moments in Dwornik's student and professional life in the first years after WWII and analyse one of the film études she made at the Film School in Łódź, in order to examine the reasons for her decision to become a film editor. This allows also to formulate some hypotheses how her career might have developed, had she been given the chance to graduate and try her hand at directing.
\end{abstract}

Key words: Zofia Dwornik; film editing; Polish cinema after WWII; Film School in Łódź; women's cinema 